\title{
HUBUNGAN PEMBERIAN IMUNISASI CAMPAK DENGAN KEJADIAN CAMPAK PADA BALITA UMUR 2-5 TAHUN DI DESA ASAN KUMBANG KECAMATAN BANDAR DUA KABUPATEN PIDIE JAYA
}

\author{
Risna Fazlaini ${ }^{*}$, Mursyidah ${ }^{2}$, Cut Nurmalawati ${ }^{3}$ \\ 1.2.3 STIKes Bumi Persada
}

\begin{abstract}
Koresponden*:
Risna Fazlaini: Program Studi D-III Kebidanan, STIkes Bumi Persada Lhokseumawe, Jl. Medan-B.Aceh, Desa Alue Awe Simpang Elak Kota Lhokseumawe, email: Risnafazlaini85@gmail.com
\end{abstract}

\begin{abstract}
ABSTRAK
Pendahuluan Campak merupakan penyakit menular dan menjadi penyebab utama kematian anak di Negara berkembang termasuk Indonesia. 1,7 juta kematian anak disebabkan oleh penyakit yang dapat dicegah dengan imunisasi, penyebab kematian anak dibawah lima tahun sebesar 5\%. Tujuan penelitian untuk mengetahui hubungan pemberian imunisasi campak dengan kejadian campak pada balita umur 2-5 tahun di desa Asan Kumbang Kecamatan Bandar Dua Kabupaten Pidie Jaya, 2019. Metode penelitian bersifat analitik dengan rancangan cross sectional. Pengambilan sampel dengan teknik total populasi, seluruh ibu yang mempunyai anak umur 2-5 tahun di Desa Asan Kumbang Kecamatan Bandar Dua Kabupaten Pidie Jaya sebanyak 39 orang. Penelitian ini tekah dilaksnakan tanggal 14-25 oktober 2019. Instrument penelitian menggunakan kuesioner. Hasil penelitian diperoleh: pada umumnya imunisasi pemberian campak tidak diberikan (23 orang/59,0\%). Balita penderita campak di Desa Asan Kumbang sebanyak 14 orang (35,9\%). Kesimpulan Ada hubungan pemberian imunisasi campak dengan kejadian campak pada balita umur 2-5 tahun ( $p$-value $=0,012)$. Rekomendsi kepada Puskesmas Bandar Dua khususnya pengelola program imunisasi sebaiknya memberikan penyuluhan tentang manfaat imunisasi campak secara continue guna meningkatkan pengetahuan masyarakat dan untuk meningkatkan partisipasi masyarakat dalam kegiatan imunisasi.
\end{abstract}

Kata Kunci: Imunisasi, Campak

ABSTRACT

Introduction Measles is a highly contagious desiase and the main cause of dath for children in developing countries, including Indonesia. It is estimated that 1,7 million child death are due to disease that can be prevented by immunization, 5\% of the cause of death for children under five years. The aim of this study was determine the relationship between measles immunization and the incidence of measles in children 2-5 years old in Asan Kumbang Village, Bandar Dua District, Pidie Jaya Regency in 2019. Method this in analytical research using crosssectional design. The total population technique was used as sampling method, consist of all mothers who have children aged 2-5 years in Asan Kumbang Village, Bandar Dua District, Pidie Jaya Regency, In total of 39 people. This research was conducted from 14-25 October 2019. The research instrument was questioners. Result this study showed that meales immunization was generally not given, as many as 23 people $(59,0 \%)$. There are 14 children under five who suffer from measles in Asan kumbang Village (35,9\%). Conclusion there is a relationship between providing measles immunization with the incidence of measles in children aged 2-5 years ( $p$-value $=0,002$ ). Recommendation to the Bandar Dua Community Health Center, especially the immunization program manager, shoul provider counseling about the benefits of measles immunization continuously in order to increase public knowledge and community participation in immunization.

Keywords: Immunisation, Measles 


\section{PENDAHULUAN}

Berdasarkan data epidemiologi di Indonesia diperoleh akumulasi anak balita yang tidak di imunisasi dan anak-anak yang tidak mendapatkan kekebalan setelah mendapatkan satu dosis vaksin campak karena efikasi vaksin campak sehingga dapat terjadi Kejadian Luar Biasa (KLB) pada kelompok ini. Pada tahun 2015 dilaporkan terjadi 188 KLB Di Indonesia dengan 3.044 kasus. Sementara itu dari laporan rutin campak didapatkan 19.111 kasus campak pada tahun 2015. Umumnya distribusi kelompok umur pada KLB dengan cakupan imunisasi yang rendah terjadi pada kelompok umur 1-4 tahun dan 5-9 tahun, sedangkan pada beberapa daerah yang cakupan imunisasi tinggi dan merata kasus campak cenderung bergeser pada kelompok umur yang lebih tua (10 tahun). Untuk mencapai percepatan perlindungan campak pada anak, dilakukan kegiatan crash programe campak terhadap anak umur 6-59 bulan dan anak usia sekolah di seluruh Provinsi sejak tahun 2005 sampai Agustus 2007, dalam 5 fase dan follow up campaign yang dilakukan bertahap sejak 2009-2011. Dengan dilakukannya berbagai upaya tersebut, diharapkan angka kematian akibat campak menurun sehingga upaya program dan wilayah endemis campak pun berkurang, Aceh memiliki 23 Kabupaten/Kota dengan jumlah penduduk yang padat, yang memungkinkan terjadinya penularan kasus campak dalam satu wilayah. Angka kejadian campak di Provinsi Aceh; 2014 terjadi 410 kasus, 2015 terjadi 508 kasus, 2016 terjadi 424 kasus, dan tahun 2017 sebanyak 321 kasus. Pidie jaya memiliki 8 kecamatan yang tersebar luas, dengan fasilitas kesehatan sebanyak 10 puskesmas. Angka kejadian penyakit campak di Kabupaten Pidie Jaya sejak bulan Januari sampai dengan bulan Desember 2016 diperoleh 63 kasus dan terjadi 1 kali Kejadian Luar biasa di Kecamatan Bandar dua. Berdasarkan latar belakang masalah tersebut, peneliti tertarik meneliti apakah ada hubungan antara pemberian imunisasi campak dengan kejadian campak di desa Asan kumbang, Kecamatan Bandar Dua, Kabupaten Pidie Jaya.

\section{METODE}

Penelitian ini menggunakan desain analitik dengan pendekatan cross Sectional Study. Sampel penelitian menggunakan teknik total populasi yaitu seluruh ibu yang memiliki anak balita umur 2-5 tahun yang berada di desa Asan kumbang sebanyak 39 orang, dengan no surat Ethical Clierance 015/C/KESBP/STIKesBPLsw/III/2020. 
Penelitian dilakukan tanggal 14-25 oktober 2019 menggunakan instrument kuesioner. Data diolah dengan teknik Editing, Coding, Transfering dan Tabulating, kemudian di analisis dengan analisa Univariat Dan Bivariat.

\section{HASIL}

Analisa univariat

a. Pemberian imunisasi Campak

Tabel 5.4 Distribusi Frekuensi

Pemberian Imunisasi Campak di desa Asan kumbang, Kecamatan Bandar Dua Kabupaten Pidie Jaya seperti terlihat pada tabel berikut:

\begin{tabular}{cccc}
\hline No & Pemberian & Jumlah & $\%$ \\
& Imunisasi & & \\
& Campak & & \\
\hline 1 & Ada & 16 & 69,0 \\
2 & Tidak ada & 23 & 41,0 \\
& Total & 39 & 100
\end{tabular}

Pada tabel diatas dapat dilihat bahwa pemberian imunisasi campak di desa Asan Kumbang Kecamatan Bandar Dua Kabupaten Pidie Jaya pada umumnya tidak diberikan yaitu sebanyak 23 orang $(59,0 \%)$, sedangkan yang ada diberikan sebanyak 16 orang $(41,0 \%)$. b. Kejadian Campak

Tabel Distribusi Frekuensi Kejadian Campak di desa Asan Kumbang Kecamatan Bandar Dua, Kabupaten Pidie Jaya Tahun 2019

\begin{tabular}{cccc}
\hline No & $\begin{array}{c}\text { Kejadian } \\
\text { Campak }\end{array}$ & Jumlah & $\%$ \\
\hline 1 & Sakit Campak & 14 & 35,9 \\
2 & Tidak sakit & 25 & 63,1 \\
& Total & 39 & 100 \\
\hline
\end{tabular}

Pada tabel diatas dapat dilihat bahwa balita yang menderita campak di desa Asan Kumbang Kecamatan Bandar Dua Kabupaten Pidie Jaya yaitu sebanyak 14 orang $(35,9 \%)$, yang tidak menderita campak 25 orang $(64,1 \%)$.

\section{Analisa Bivariat}

Tabel 5.6 Hubungan pemberian imunisasi campak dengan kejadian campak pada balita umur 2-5 tahun di Desa Asan kumbang Kecamatan Bandar Dua Kabupaten Pidie Jaya.

\begin{tabular}{|c|c|c|c|c|c|c|c|}
\hline \multirow{4}{*}{ Pemberian inun } & \multicolumn{4}{|c|}{ Kejadian Catmpak } & \multirow{2}{*}{\multicolumn{2}{|c|}{ Jutrilah }} & \multirow{4}{*}{ p-Value } \\
\hline & & & & & & & \\
\hline & \multicolumn{2}{|c|}{ Sakit } & \multicolumn{2}{|c|}{ Tidak } & \multirow[b]{2}{*}{ f } & \multirow[b]{2}{*}{$\%$} & \\
\hline & f & $\%$ & $\mathrm{f}$ & $\%$ & & & \\
\hline Ada & 2 & 12.5 & 14 & 87.5 & 16 & 100 & \\
\hline Tidak & 12 & $52: 2$ & 11 & 47.8 & 23 & 100 & 0,012 \\
\hline Total & 14 & 35.9 & 25 & 64.1 & 39 & 100 & \\
\hline
\end{tabular}

\section{PEMBAHASAN}

Hasil penelitian terlihat bahwa pemberian imunisasi campak di desa Asan Kumbang Kecamatan Bandar Dua 
Kabupaten Pidie Jaya pada umumnya tidak diberikan yaitu sebanyak 23 orang $(59,0 \%)$, sedangkan yang ada diberikan sebanyak 16 orang $(41,0 \%)$. Balita yang menderita campak di desa Asan Kumbang Kecamatan Bandar Dua Kabupaten Pidie Jaya sebanyak 14 orang (35,9\%), sedangkan yang tidak menderita campak 25 orang $(64,1 \%)$. Berdasarkan uji statistik menggunakan chi square diketahui $p$-value $=0.012$ berarti ada hubungan antara pemberian imunisasi campak dengan kejadian campak pada balita umur 2-5 tahun Di Asan Kumbang Kecamatan Bandar Dua Kabupaten Pidie Jaya Tahun 2019.

Rendahnya pemberian imunisasi pada balita di Desa Asan Kumbang Kecamatan Bandar Dua Kabupaten Pidie Jaya disebabkan beberapa faktor diantaranya ibu yang enggan diimunisasi anaknya dikarenakan takut anaknya demam pada malam hari dan takut dimarahi oleh suaminya. Disamping itu, faktor yang sangat mempengaruhi adalah isu vaksin yang tidak halal (mengandung lemak babi) yang menyebabkan ibu-ibu tidak mau memberikan imunisasi kepada anaknya. Disamping itu kurangnya pengetahuan ibu tentang manfaat imunisasi sangat signifikan terhadap keikutsertaan dalam memberikan imunisasi campak kepada balitanya. Hasil penelitian Siregar pada KLB di Bogor pada tahun 2002, ibu yang mempunyai pengetahuan rendah, anaknya mempunyai resiko 2,03 kali menderita campak dibandingkan dengan ibu yang mempunyai pengetahuan cukup. Begitu juga hasil penelitian di Jakarta Selatan ibu yang mempunyai pengetahuan rendah anaknya mempunyai risiko menderita campak sebesar 2,1 kali dibandingkan pengetahuan tinggi (Purnomo, 2006).

Setiap individu akan berpengaruh terhadap perlindungan kelompok dari serangan infeksi campak di wilayah tersebut (Fine \& Paul, 1993). Hal ini sejalan dengan penelitian yang dilakukan pada sekelompok anak usia 12-24 bulan di Kodya Jakarta Selatan yang tidak di imunisasi mempunyai risiko 2,53 kali menderita campak. Demikian juga di Kabupaten Serang, anak yang tidak di imunisasi campak mempunyai risiko 1,21 kali mendeita campak dibandingkan anak yang tidak di imunisasi (Padri, 2009). Penelitian yang dilakukan oleh Haryanto (2013) di Kabupaten Kebumen menyebutkan bahwa meskipun telah mendapatkan imunisasi campak pada umur 9-10 bulan, namun masih dijumpai titer antibodi campak negatif. Hal tersebut kemungkinan dipengaruhi oleh beberapa fakor diantaranya daya guna vaksin campak 
belum maksimal, strain vaksin yang digunakan, faktor kematangan sistem imun tubuh, faktor genetik yang membuat respon imun terbatas, kemungkinan adanya antibodi maternal pada saat imunisasi sehingga antigen vaksin akan diikat oleh antibodi yang terdapat dalam tubuh dan respon imun tidak terbentuk.

Berdasarkan hasil penelitian Harjani (2011) masalah imunisasi campak dapat dilihat dari 3 (tiga) aspek meliputi vaksin campak yang kebanyakan berasal dari produk resmi dari Kementerian Kesehatan RI yang kebanyakan berasal dari Biofarma, penerima vaksin yang tidak tepat sasaran karena dipengaruhi oleh lingkungan keluarga, sosial dan budaya, dan sikap petugas kesehatan sebagai pelaksana program dan tokoh masyarakat sebagai penunjang program. Pengelola program imunisasi harus memiliki kemampuan dalam menentukan jumlah sasaran imunisasi, target cakupan, perhitungan vaksin dan sarana yang ada dan penyusunan jadwal disesuaikan dengan kondisi situasi wilayah. Hal ini nantinya akan mensukseskan program imunisasi campak agar tidak terjadi KLB.

\section{KESIMPULAN}

1. Pemberian imunisasi campak di Desa Asan Kumbang Kecamatan Bandar Dua
Kabupaten Pidie Jaya pada umumnya tidak diberikan yaitu sebanyak 23 orang $(59,0 \%)$, sedangkan yang diberikan imunisasi sebanyak 16 orang $(41,0 \%)$.

2. Balita yang menderita campak di Desa Asan Kumbang Kecamatan Bandar Dua Kabupaten Pidie Jaya yaitu sebanyak 14 orang $(35,9 \%)$, sedangkan yang tidak menderita campak sebanyak 25 orang $(64,1 \%)$.

3. Ada hubungan antara pemberian imunisasi campak dengan kejadian campak pada balita usia 2-5 tahun di Desa Asan Kumbang Kecamatan Bandar Dua Kabupaten Pidie Jaya ( $\mathrm{p}$-valu = 0,012).

\section{UCAPAN TERIMAKASIH}

1. Drs H. Bukhari Yusuf selaku Pembina Yayasan STIKes Bumi Persada Lhokseumawe

2. Hj. Tuti Rawati selaku Ketua Yayasan STIKes Bumi Persada Lhokseumawe

3. Rika Mursyida, S.SiT., M.Kes selaku Ketua STIKes Bumi Persada Lhokseumawe

4. Ns. Fauzan Saputra, S.Kep,. MNS wakil ketua I bidang Akademik

5. Suami dan anak-anak yang selalu menjadi alasan untuk tetap semangat dan amanah dalam mengemban ilmu. 


\section{REFERENSI}

Atikah P: (2010). Imunisasi dan Vaksinasi.

Yogyakarta: Nuha Medika.

Azwar, Saifuddin (2010). Sikap Manusia: Teori dan Pengukurannya. Yogyakarta: Liberty.

Bimo, Walgito. (2010). Pengantar Psikologi Umum. Yogyakarta: C.V Andi

Casaeri (2003) Faktor Risiko Kejadian Campak Di Kabupaten Kendal tahun 2002. Semarang: Universitas Diponegoro.

Efriyanti A. (2009). Faktor- Faktor Yang Berhubungan Dengan Cakupan Imunisasi Campak Di Kabupaten Tegal. In. Edited by Semarang UN

Gerungan, W.A. (2004). Psikologi Sosial. Bandung : PT. Refika Aditama, IKAPI.

Giarsawan N. Faktor Faktor Yang Mempengaruhi Kejadian Campak di Wilayah Puskesmas Tejakula I Kecamatan Tejakula Kabupaten
Buleleng Tahun 2012. Jurnal Kesehatan Lingkungan 2014, Vol 4 No 2.

Hidayat, Alimul (2008). Pengantar Ilmu Keperawatan Anak. Salemba Medika Nadhirin: (2010). Campak di Indonesia. Jakarta : Buletin Epidemiologi

Natalya D. (2011). Analisis Kejadian Campak Pada Anak Balita Di Kelurahan Tegal Sari Mandala III Kecamatan Medan Denai Tahun 2010. Skripsi Universitas Helvetia, Medan.

Notoatmodjo S. (2007) Prinsip Prinsip Dasar 